\title{
LASIK interface primary complications
}

\section{Complicações primárias da interface do 'flap' de LASIK}

\author{
Renata Loures Bueno de Moraes', Vinícius Coral Ghanem ${ }^{2}$, Ramon Coral Ghanem³, Marcony R. Santhiago ${ }^{4}$
}

\begin{abstract}
Laser in situ Keratomileusis (LASIK) is one of the most accepted techniques in refractive surgery today. Its predictability, reproducibility, safety and low incidence of side effects justify the wide diffusion of this technique. This is a laser surgical procedure which purpose consists in the modification of corneal structure, allowing a shift of the focal point of the eye. Thus, it is possible to correct refractive errors such as myopia, astigmatism and small degrees of hyperopia. The LASIK technique creates a corneal flap interface with the use of a microkeratome or femtosecond laser. Then, excimer laser is applied on the stroma bed followed by repositioning of the flap, creating an interface between the anterior and posterior corneal lamella. Despite the numerous advantages there are patologies that originate from primary complications of the interface which can caused confusion during diagnosis because they have similarities in their clinical presentation. The aim of this work is to define, characterize and compare those entities with the intention of making the diagnosis easier so that there is appropriate conduct. As result, this study presents recommendations for the management of each kind of interface disease through investigation by medical history and physical examination, in order to allow differential diagnosis between the main primary entities of the LASIK procedure interface.
\end{abstract}

Keywords: Keratomileusis, laser in situ/adverse effects; Ophthalmological surgical procedures/adverse effects

\section{RESUMO}

Laser in situ Keratomileusis (LASIK) é uma das técnicas mais aceitas na cirurgia refrativa atualmente. Sua previsibilidade, reprodutibilidade, segurança e baixos índices de efeitos colaterais justificam a ampla difusão dessa técnica. Trata-se de um procedimento cirúrgico a laser cujo objetivo consiste na modificação da estrutura corneana, permitindo uma mudança do ponto focal do olho. Dessa forma, é possível corrigir ametropias tais como a miopia, astigmatismo e pequenos graus de hipermetropia. A técnica do LASIK consiste na criação de um flap corneano por meio da utilização de um microcerátomo ou do laser de femtossegundo. Em seguida, é realizada a aplicação do excimer laser sobre o leito estromal com posterior reposicionamento do flap, criando-se uma interface entre as lamelas anterior e posterior da córnea. Apesar das inúmeras vantagens, existem patologias que resultam de complicações primárias da interface do flap, que podem causar confusão no momento do diagnóstico, por possuírem semelhanças quanto à sua apresentação clínica. $\mathrm{O}$ objetivo desse trabalho é definir, caracterizar e comparar tais entidades com intuito de facilitar o diagnóstico diferencial dessas patologias evitando a adoção de um tratamento equivocado. Como resultado do estudo, são apresentadas recomendações quanto à conduta nos casos de cada patologia de interface, com investigação por meio da anamnese e exame clínico, a fim de permitir diagnóstico diferencial entre as principais entidades primárias da interface do procedimento LASIK.

Descritores: Ceratomileuse assistida por excime laser in situ/efeitos adversos; Procedimentos cirúrgicos oftalmológicos/efeitos adversos

\footnotetext{
${ }^{1}$ Fellow of Cornea and Refractive Surgery at the Hospital de Olhos Sadalla Amin Ghanem, SC, Brazil.

${ }^{2,3}$ Ophthalmologist at the Hospital de Olhos Sadalla Amin Ghanem, SC, Brazil.

${ }^{4}$ Department of Ophthalmology, Universidade de São Paulo, São Paulo, SP, Brazil.
}

The authors declare no conflicts of interests.

Received for publication 08/12/2014 - Accepted for publication 23/01/2015 


\section{INTRODUCTION}

Laser in situ keratomileusis (LASIK) is considered a standard, safe and effective procedure indicated mainly for the correction of low and medium ametropies. However, as in any surgical procedure, complications are described and must be actioned in accordance with the protocols and scientific knowledge acquired by the expert. Interface complications can occur due to the space created between the flap and corneal stroma, thereby allowing the accumulation of fluids or cells that can promote biochemical processes, including reorganization and cell accumulation ${ }^{(1)}$.

The interface of LASIK can be affected by infectious and inflammatory causes, causing different types of opacities. One of the main primary inflammatory causes is the diffuse lamellar keratitis (DLK), pressure-induced stromal keratitis (PISK), epithelial growth and central toxic keratitis (CTK). Such complications can arise from various etiologies whose clinical presentations can overlap. Interface material can also be present, as well as deposits derived from various organic and inorganic sources that can be confused with serious disorders, resulting in erroneous diagnoses and treatments. The differentiation between these entities is critical for proper diagnosis, treatment and the final visual results. Although there are initial similarities, a thorough anamnesis with detailed description of the signs and symptoms, time and onset of clinical condition, along with a targeted examination, promotes a significant increase to the correct initial diagnosis, and thus the onset of the treatment protocol according to the pathology. In cases of overlap between the diseases, there should be frequent monitoring in the immediate postoperative period, so that this way an accurate diagnosis and the institution of the necessary changes in treatment are allowed.

Among the interface complications, DLK is most common one, and infectious keratitis is usually the most severe pathology $y^{(2,3)}$. The distinction between the infectious and inflammatory forms is the first step for the proper treatment and visual recovery of the patient. Some findings as the involvement only of the interface without stromal invasion, besides the absence of palpebral edema, ciliary injection, keratic or hypopyon precipitates are suggestive of inflammatory etiology, since the presence of these signs associated to symptoms such as pain, photophobia, and decreased visual acuity suggest an infectious condition ${ }^{(4)}$. The epithelialization of the interface is usually the easiest entity to be diagnosed and treated. However, it may be associated with other interface disorders.

The rarity makes the initial diagnosis increasingly challenging for less experienced surgeons.

The complications of the interface can have a focal or diffuse appearance, be with or without conjunctival hyperemia, with or without foreign body sensation, and its duration may vary from a day to three or four weeks from the postoperative period.

It is important to determine the diagnosis quickly, because the appropriate action can be distinguished, including being exactly contrary to the right treatment, depending on its etiology.

Diffuse Lamellar Keratitis (DLK) or Sands of the Sahara Syndrome

The diffuse lamellar keratitis is one of the most common postoperative complications of LASIK procedure. It was first described by Robert Maddox in ASCES in 1996 and published by Smith and Maloney in 1998, being defined as an inflammatory condition characterized by a fine-grained, grayishwhite reaction with the presence of blood cells coalescing between the flap and the stromal bed, starting in the early days of the procedure(2). The test to confirm the presence of inflammatory cells between the interface and the corneal stroma is the confocal microscopy ${ }^{(5)}$. This nonspecific inflammation is strongly related to intraepithelial defects ${ }^{(6)}$, and has been linked to multiple triggering factors ${ }^{(7)}$. However, in most cases, especially in epidemic DLK, it has been associated to the presence of bacterial endotoxins ${ }^{(2,8,9)}$, meibomian glandular secretions and peripherals immune infiltrates, atopy, iatrogenic epithelial defects or resulting from problems during the process of sterilization of instruments, related for example to gloves and surgical marking pens. Finally, DLK is probably the result of endogenous risk factors of the patient in response to exogenous exposure ${ }^{(10)}$, though isolated cases of idiopathic DLK have also been sporadically observed ${ }^{(11)}$. However, if many cases happen in a short period of time, precautions should be taken to assess sterilization process ${ }^{(2,8)}$. The late onset of DLK has also been described in the literature ${ }^{(12)}$. However, most of these cases probably have a specific causal factor. The diffuse lamellar keratitis can manifest as eye pain, photophobia, foreign body sensation and reduced visual acuity.

There are several classifications for severity and treatment of the condition. According to Linebarger, DLK is divided into four phases according to its clinical presentation ${ }^{(10)}$ : (Figure 1)

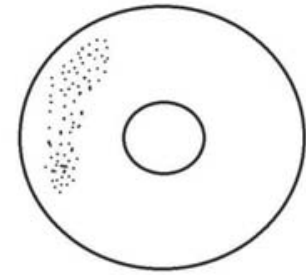

A) DLK Phase 1 - granular deposits in the periphery that coalesce at the interface

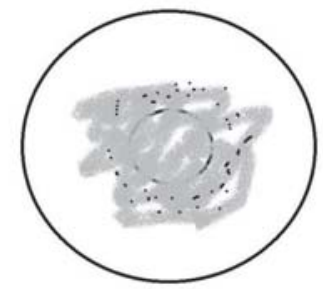

C) DLK Phase 3 - Some inflammatory cells, large streaks, diffuse haze

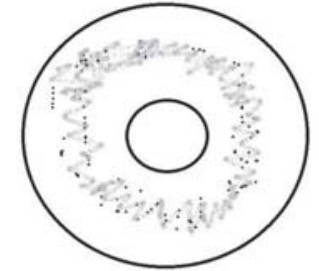

B) DLK Phase 2 - diffuse infiltrate with paracentral centripetal distribution sparing the central axis

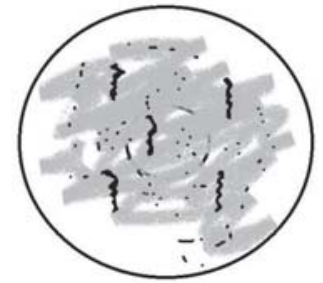

D) DLK Phase 4 - Some inflammator cells, large streaks, diffuse haze
Figure 1: Classification of DLK

Diffuse lamellar keratitis seems to be slightly more common with the use of femtosecond laser compared to the microkeratome for making the flap. Studies have shown that high levels of laser energy result in tissue injury induced by photodisruption, causing accumulation of gas bubbles which may lead to an increased inflammatory response of DLK. However, most of these cases seem to be mild and cured with appropriate treatment without further complications ${ }^{(13,14,15)}$. 
The action in diffuse lamellar keratitis is based on the use of steroids, being such etiology highly sensitive to this drug. Topical steroids are used for mild cases, and a combination of topical and oral steroids for mooderate cases ${ }^{(2,15,16)}$. Many surgeons advocate the use of oral steroids in phases 2 and 3 of DLK associated to elevation and irrigation of the flap for phase 2 and which are not responding quickly to the treatment and all cases in phase $3^{(2,15,16)}$. For stage 4, the steroids may be used in order to minimize the scar density and can be partially effective, and elevating the flap is controversial ${ }^{(10,15)}$. Some surgeons advocate cautious raising of the flap and irrigation to remove toxins, but such action should be performed extremely carefully and measures should be taken to prevent the loss of tissue, that is why some authors defend not elevating the flap at this stage ${ }^{(10)}$.

The uncorrected and corrected visual acuity after the treatment of DLK is usually $\operatorname{good}^{(2,8,11)}$. However, such a result could be misleading, since the DLK seems to affect the visual quality and sensitivity to contrast more than the absolute Snellen acuity measures ${ }^{(17)}$.

Diffuse lamellar keratitis often induces a mild to moderate hyperopia after its resolution, with both regular and irregular astigmatism, especially in stage $4^{(17)}$. If the persisting ametropy is significant, patients can undergo treatment again, without increased risk of developing DLK in a second moment. For phase 4, the retreatment can still be justified if the refractive error is not irregular, but in such cases the surface ablation is a better option than the elevation of the flap for the reasons mentioned above.

\section{Pressure Induced Stromal Keratitis (PISK)}

PISK is an interface entity that is presented as a corneal opacity, usually occurring weeks or months after LASIK and being associated to elevated intraocular pressure and worsening after treatment with steroids. There is evidence that such pathology is the result of abnormal fluid dynamics that occurs in the cornea after such procedure ${ }^{(18)}$. It is an important differential diagnosis of interface pathologies, since such pathology can simulate the clinical condition of other inflammatory keratitis and result in a significant visual loss even in patients without associated comorbidities.

The treatment with steroids can result in an increased intraocular pressure, with consequent accumulation of fluid in the interface. The amount of this fluid can be relatively small, which results in diffuse opacification of the interface, also overlapping in the cornela stroma ${ }^{(19)}$, or may be a more pronounced condition resulting in a fluid visible to the optical biomicroscopy which separates the anterior flap from the posterior residual bed ${ }^{(20)}$. When compared to other complications of the interface, PISK seems to be an entity more difficult to be diagnosed due to the confusing terminology present in the literature and the wide variety of forms of presentation at the physical examination. Regarding the nomenclature, several names have been given to the many manifestations of this entity, resulting in confusion in the diagnostic criteria, making them wrong several times. Among the most common terms are pressure induced stromal keratitis (PISK) ${ }^{(19)}$, pressure-induced interface keratitis $^{(21)}$ and interface fluid syndrome ${ }^{(22)}$. "Keratitis" is a misnomer in the definition of such entity, since during the evaluations with confocal microscopy it has been demonstrated that there was no inflammation of the keratocytes present in such complication ${ }^{(23)}$. The term interface fluid syndrome is technically correct; however, the interface fluid syndrome can occur from a variety of mechanisms independent of steroids acute response in the early postoperative period. Many experts state that such term means in fact that the fluid present in the interface is easily visible. Therefore, although the use of such a definition is consistent, the recommendation would be to avoid the routine use of this term when the intention is to convey information about this entity, which happens in the immediate postoperative period with the association of steroids, which can be with or without fluid in the interface noticeable with the exam of optical biomicroscopy. Recently, Tourtas and Cursiefen ${ }^{(24)}$ created the term pressure induced stromal keratitis", which maintains the term PISK, being such abbreviation the most used one, while also transmits accurately and more efficiently the etiology of the disease. The significant variability of the presentation from the view of the diffuse opacities of the interface in the physical examination and demonstrating the presence of fluid requires diligence in establishing the diagnosis, differentiating this DLK condition and starting the appropriate treatment strategy. The degree of accumulation of interface fluid underestimates the true value of intraocular pressure (IOP), when assessed using the standard method of measurement of eye pressure. This fact is due to the interface damping effect when in reality the IOP is higher than that obtained by the tonometer. Therefore, any increase in intraocular pressure after LASIK deserves investigation and careful monitoring. Where the IOP measurements are carried out by conventional methods with suspect results, alternatives should be tried in order to determine a more reliable IOP, including IOP measurements in peripheral corneal regions with applanation by Goldmann tonometer or Tonopen ${ }^{(25)}$. The dynamic contour tonometry (e.g., Pascal tonometer) can also be used to assess reliably the IOP, since it has proved to be relatively resistant to biomechanical and pachymetric corneal changes after LASIK ${ }^{(26)}$. The proper action of this complication includes the suspension of the use of steroids and the onset of anti-glaucomatous topical medications, in order to reduce the IOP and solve the accumulation of fluids ${ }^{(19,20)}$. If the diagnosis is identified early and an action is followed properly, the patients usually recover well and without loss of corrected visual acuity ${ }^{(19)}$. Otherwise, a severe loss of central visual acuity can occur ${ }^{(20)}$.

\section{Epithelial Growth}

The epithelial growth is an infrequent complication observed in approximately $1-2 \%$ of cases, usually occurring in the first three weeks of the postoperative period. It occurs due to the migration of epithelial cells, originally outside the flap, which invade flap-stroma interface and focus on the peripheral edge of the cornea. (Figure 2) Although the epithelial growth tends to be self-limited, occasionally there may be an increase in this cell growth, promoting stromal keratolysis and irregular astigmatism $^{(26)}$. In most cases, epithelial growth happens outside the visual axis, and it is possible only to observe the condition without the need for treatment ${ }^{(27)}$. Risk factors were associated to such entity, as the presence of prior corneal incisions (post radial keratotomy or transplant), reoperation with flap elevation, especially in late stages, in addition to the correction of hypermetropia due to greater ablation in the flap margin.

Epithelial growth can be classified in relation to its severity in ${ }^{(28)}$ :

Level 1: little thickness, with demarcation line less than 2 $\mathrm{mm}$ from the flap border, usually not progressive and not requiring treatment. 
Level 2: extension greater than $2 \mathrm{~mm}$, without demarcation line, easily identified by examination, associated to the elevation of the flap borders. It must be monitored and the treatment planned if there is progression within two to three weeks.

Level 3: multicellular thickness, located more than $2 \mathrm{~mm}$ from the flap borders, being characterized by whitish areas of necrotic epithelial cells and wrinkled flap borders, erosadas and thick which usually progresses to melting secondary to the release of collagenases by necrotic cells. Confluent haze may occur, and also the detachment of the flap from its bed.

In some cases as the extension of the lesion in the visual axis and to the pupillary border, focal elevation the flap, focal elevation of the flap border, decreased visual acuity, increased glare, induction of irregular astigmatism, foreign body sensation and local presence in of melt in the corneal flap the treatment may be necessary according to the cause ${ }^{(29)}$.

The incidence of primary epithelial growth is associated to the internal growth due to mechanical microkeratome use when compared to the femtosecond laser for the creation of the flap ${ }^{(30,31)}$, and the use of contact lenses after LASIK retreatment is associated with an increase in its incidence ${ }^{(32)}$. Recently Wilson and Santhiago described a technique of post LASIK flap elevation by femtosecond that significantly decreases the risk of epithelial growth. ${ }^{(33,34)}$

Most cases are mild and with few clinical manifestations, with the conduct being observation of the condition. When necessary, the initial surgical treatment of epithelial growth is accomplished with the elevation of the flap, removal of epithelial cells from the posterior surface of the flap and the stromal bed with a knife or similar instrument, and replacement of the flap without sutures or adhesive tissues ${ }^{(29)}$. In case of recurrent episodes of epithelial growth, additional measurements are typically made, including suturing the flap ${ }^{(35)}$ (Figure 3), fibrin glue $^{(36)}$ or yag laser treatment ${ }^{(37)}$.

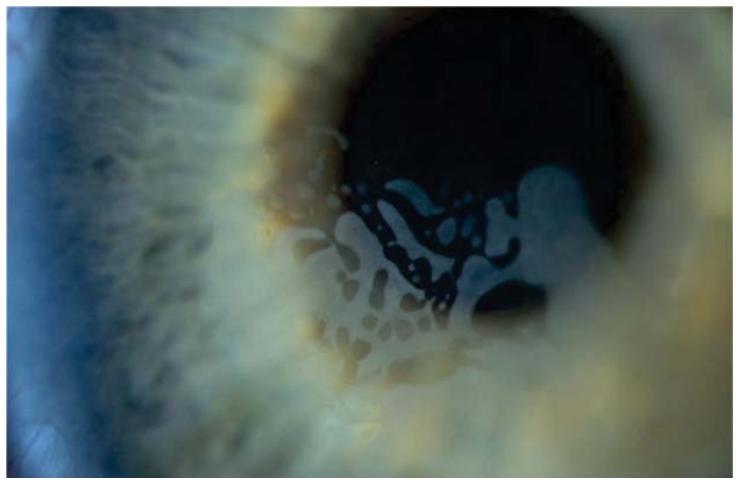

Figura 2: Presence of epithelial invasion of expanding centripetally through the flap interface.

\section{Central Toxic Keratitis (CTK)}

The central toxic keratopathy is a rare, acute disease, presenting as central stromal opacification, deep stromal folds, and flattening of the central corneal region generating hyperopia. Normally, such etiology happens between three and nine days after the LASIK procedure with no complications. The pathology is not restricted to flap interface, and the location of opacities and scars is more prominent in the areas where higher concentrations occured during the laser treatment. Its etiology is unknown and could be related to enzymatic degradation of

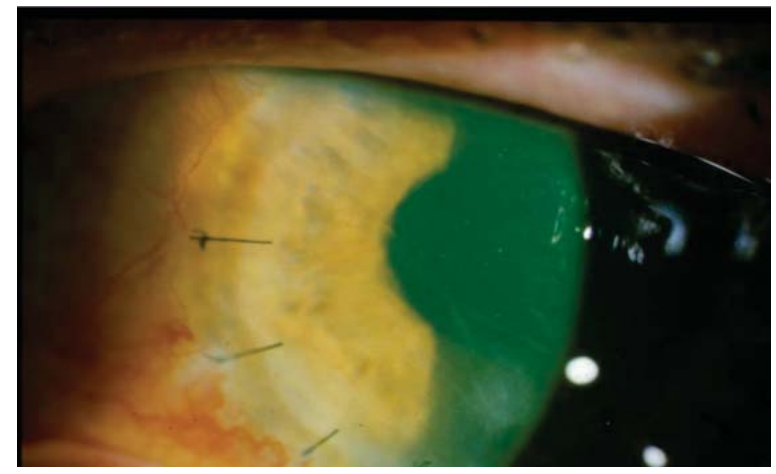

Figura 3: Flap suture performed after the removal of epithelial cells at the interface region

the keratocytes ${ }^{(38)}$. The confocal microscopy examination showed activation of keratocytes without inflammatory cells, with loss of the same in the stromal bed and gradual local restocking ${ }^{(39)}$. The CTK does not worsen over time, unlike most other entities. However, certain features have similarities with other severe inflammatory conditions, including DLK. Despite the clinical features overlap, especially in phase 4 of the DLK, soon a correct diagnosis is needed, since the conduct is distinct ${ }^{(28)}$.

CTK has an acute and almost always painless onset, unlike DLK which, in most cases, has at least one foreign body sensation and progresses over time if the correct treatment is not established. The central toxic keratopathy is self-limited, and the treatment may not be enough to solve the clinical condition ${ }^{(38)}$. Although some authors defend the aggressive use of topical steroids ${ }^{(40)}$ or the elevation and irrigation of the flap ${ }^{(41)}$, most believe that a surgical intervention does not contribute to the improvement of the condition and may even worsen the final results ${ }^{(38)}$. The recovery in most patients is good, but the corneal opacity and significant changes of visual acuity can remain ${ }^{(28)}$.

\section{ConClusão}

The opacity of the LASIK interface can be infectious or inflammatory, and this distinction is the first step to proper treatment and visual recovery of the patient. DLK is an inflammatory condition which presents as a risk factor epithelial defects, taking place in the first five days after surgery, unlike infectious keratitis which is often later. The opacities are more diffuse and may be associated to a slight flare or rare cells present in the anterior chamber, and its response to treatment with corticosteroids is dramatic.

CTK is a clinical entity of early onset which simulates DLK, especially in stage 4. However, it does not evolve over time, unlike DLK which takes more time to become a condition similar to that of CTK. Finally, PISK starts in about two weeksm, showing that the intraocular pressure measure is of key ortance in the postoperative period of LASIK, and corticosteroid should be promptly discontinued if it is high.

Interface entities are often presented with overlap of clinical characteristics, but with different mechanisms and diverse behaviors (Table 1). The expert should be aware of these specific features which guide him quickly to the appropriate diagnosis and optimized conduct. Therefore, a careful anamnesis concomitant to directed clinical examination becomes imperative. 
Table 1

Conduct in the interface etiologies after LASIK

\begin{tabular}{ll|c|c}
\hline Etiology & Primary intervention & Secondary intervention & Incorrect conduct and strategies \\
\hline DLK & Corticosteroids & Elevation and irrigation of the flap & Lack of use of corticosteroids \\
\hline PISK & $\begin{array}{c}\text { Discontinue the use } \\
\text { of corticosteroids }\end{array}$ & Topic antiglaucoma drugs & Continuous use of corticosteroids \\
\hline CTK & Observation & Observation & Elevation of the flap \\
\hline $\begin{array}{l}\text { Epithelial } \\
\text { Growth }\end{array}$ & $\begin{array}{l}\text { Observation in case it } \\
\text { happens in the peferia } \\
\text { of the flap }\end{array}$ & $\begin{array}{c}\text { Elevation of the flap /removal of cells / } \\
\text { suture of the flap or fibrin glue }\end{array}$ & $\begin{array}{c}\text { Observation in case of viewing } \\
\text { an epithelial growth that has } \\
\text { criteria for surgical intervention }\end{array}$ \\
\hline
\end{tabular}

$\overline{\mathrm{DLK}}=$ diffuse lamellar keratectomy, PISK = pressure induced stromal keratitis, CTK = central toxic keratopathy

\section{ReFERENCES}

1. Knorz MC. Complications of refractive excimer laser surgery. Ophthalmologe. 2006; 103(3):192-8.

2. Stulting RD, Randleman JB, Couser JM, Thompson KP. The epidemiology of diffuse lamellar keratitis. Cornea. 2004;23(7):680-8.

3. Llovet F, de Rojas V, Interlandi E, Martín C, Cobo-Soriano $\mathrm{R}$, Ortega-Usobiaga J, et al. Infectious keratitis in 204586 LASIK procedures. Ophthalmology. 2010;117(3):232-8.

4. Chang MA, Jain S, Azar DT. Infections following laser in situ keratomileusis: an integration of the published literature. Surv Ophthalmol. 2004;49(3):269-80.

5. Buhren J, Baumeister M, Cichocki M, Kohnen T. Confocal microscopic characteristics of stage 1 to 4 diffuse lamellar keratitis after laser in situ keratomileusis. J Cataract Refract Surg. 2002;28(8):1390-9.

6. Shah MN, Misra M, Wihelmus KR, Koch DD. Diffuse lamellar keratitis associated with epithelial defects after laser in situ keratomileusis. J Cataract Refract Surg. 2000;26(9):1312-8.

7. Gritz DC. LASIK interface keratitis: epidemiology, diagnosis and care. Curr Opin Ophthalmol. 2011;22(4):251-5.

8. Holland SP, Mathias RG, Morck DW, Chiu J, Slade SG. Diffuse lamellar keratitis related to endotoxins released from sterilizer reservoir biofi lms. Ophthalmology. 2000;107(7):1227-33.

9. Yuhan KR, Nguyen L, Wachler BS. Role of instrument cleaning and maintenance in the development of diffuse lamellar keratitis. Ophthalmology. 2002;109(2):400-3.

10. Linebarger EJ, Hardten DR, Lindstrom RL. Diffuse lamellar keratitis: diagnosis and management. J Cataract Refract Surg. 2000; 26(7):1072-7.

11. Wilson SE, Ambrosio R Jr. Sporadic diffuse lamellar keratitis (DLK) after LASIK. Cornea. 2002;21(6):560-3.

12. Kymionis GD, Diakonis VF, Bouzoukis DI, Lampropoulou I, Pallikaris AI. Idiopathic recurrence of diffuse lamellar keratitis after LASIK. J Refract Surg. 2007;23(7):720-1.

13. Binder PS. One thousand consecutive IntraLase laser in situ keratomileusis flaps. J Cataract Refract Surg. 2006;32(6):962-9.

14. Moshirfar M, Gardiner JP, Schliesser JA, Espandar L, Feiz V, Mifflin MD, Chang JC. Laser in situ keratomileusis flap complications using mechanical microkeratome versus femtosecond laser: retrospective comparison. J Cataract Refract Surg. 2010;36(11):1925-33.

15. Hoffman RS, Fine IH, Packer M. Incidence and outcomes of LASIK with diffuse lamellar keratitis treated with topical and oral corticosteroids. J Cataract Refract Surg. 2003;29(3):451-6.
16. MacRae SM, Rich LF, Macaluso DC. Treatment of interface keratitis with oral corticosteroids. J Cataract Refract Surg. 2002;28(3):454-461.

17. Javaloy J, Alió JL, El Kady B, Muñoz G, Barraquer RI, Maldonado MJ. Refractive outcomes and quality of vision related to an outbreak of diffuse lamellar keratitis. J Refract Surg. 2011;27(11):804-10.

18. Lee V, Sulewski ME, Zardi A, Nichols CW, Bunya VY. elevated intraocular pressure induced interlamellar stromal keratitis occurring 9 years after laser keratoumileusis. Cornea. 2012;31(1):87-9

19. Belin MW, Hannush SB, Yau CW, Schultze RL. Elevated intraocular pressure-induced interlamellar stromal keratitis. Ophthalmology. 2002;109(10):1929-33.

20. Hamilton DR, Manche EE, Rich LF, Maloney RK. Steroid-induced glaucoma after laser in situ keratomileusis associated with interface fl uid. Ophthalmology. 2002;109(4):659-65.

21. Nordlund ML, Grimm S, Lane S, Holland EJ. Pressure-induced interface keratitis: a late complication following LASIK. Cornea. 2004;23(3):225-34.

22. Dawson DG, Schmack I, Holley GP, Waring GO III, Grossniklaus $\mathrm{HE}$, Edelhauser HF. Interface fl uid syndrome in human eye bank corneas after LASIK: causes and pathogenesis. Ophthalmology. 2007;114(10):1848-59.

23. Kurian M, Shetty R, Shetty BK, Devi SA. In vivo confocal microscopic fi ndings of interlamellar stromal keratopathy induced by elevated intraocular pressure. J Cataract Refract Surg. 2006;32(9):1563-16.

24. Tourtas T, Cursiefen C. "PISK-itis" or "PISK-opathy"? Cornea. 2011;31(2):107.

25. Wheeldon CE, Hadden OB, Niederer RL, McGhee CN. Presumed late diffuse lamellar keratitis progressing to interface fl uid syndrome. J Cataract Refract Surg. 2008;34(2):322-326.

26. Pepose JS, Feigenbaum SK, Qazi MA, Sanderson JP, Roberts CJ. Changes in corneal biomechanics and intraocular pressure following LASIK using static, dynamic, and noncontact tonometry. Am J Ophthalmol. 2007;143(1):39-47.

27. Asano-Kato N, Toda I, Hori-Komai Y, Nakano Y, Dogru M, Tsubota K.Histopathological findings of epitelial ingrowth after laser in situ keratoumileusis. Cornea. 2005;24(2):130-4

28. Hazin R, Daoud YJ, Khalifa YM. What is central toxic keratopathy syndrome if it is not diffuse lamellar keratitis grade IV? Middle East Afr J Ophthalmol. 2010;17(1):60-2.

29. Wang MY, Maloney RK. Epithelial ingrowth after laser in situ keratomileusis. Am J Ophthalmol. 2000;129(6):746-51.

30. Chen S, Feng Y, Stojanovic A, Jankov MR II, Wang Q. IntraLase femtosecond laser vs mechanical microkeratomes in LASIK for myopia: a systematic review and meta-analysis. J Refract Surg. 2012;28(1):15-24. 
31. Santhiago MR, Kara-Junior N, Waring GO 4th. Microkeratome versus femtosecond flaps: accuracy and complications. Curr Opin Ophthalmol. 2014;25:270-4.

32. Chan CC, Boxer Wachler BS. Comparison of the effects of LASIK retreatment techniques on epithelial ingrowth rates. Ophthalmology. 2007;114(4):640-2.

33. Wilson SE, Santhiago MR.Flaporhexis: rapid and effective technique to limit epithelial ingrowth after LASIK enhancement. J Cataract Refract Surg. 2012;38(1):2-4.

34. Santhiago MR, Smadja D, Zaleski K et al. Flap relift for retreatment after femtosecond laser-assisted LASIK.J Refract Surg. 2012 Jul;28(7):482-7.

35. Rojas MC, Lumba JD, Manche EE. Treatment of epithelial ingrowth after laser in situ keratomileusis with mechanical debridement and fl ap suturing. Arch Ophthalmol. 2004;122(7):9971001 .
36. Yeh DL, Bushley DM, Kim T. Treatment of traumatic LASIK flap dislocation and epithelial ingrowth with fi brin glue. Am J Ophthalmol. 2006;141(5):960-2.

37. Ayala MJ, Alió JL, Mulet ME, De La Hoz F. Treatment of laser in situ keratomileusis interface epithelial ingrowth with neodymium:yytrium-aluminum-garnet laser. Am J Ophthalmol. 2008;145(4):630-4.

38. Sonmez B, Maloney RK. Central toxic keratopathy: description of a syndrome in laser refractive surgery. Am J Ophthalmol. 2007;143(3):420-7.

39. Thornton IL, Foulks GN, Eiferman RA. Confocal microscopy of central toxic keratopathy. Cornea. 2012;31(8):934-6.

40. Lyle WA, Jin GJ. Central lamellar keratitis. J Cataract Refract Surg. 2001;27(4):487-90.

41. Tu KL, Aslanides IM. Surgical intervention in central toxic keratopathy [published online ahead of print March 5, 2012] European Journal of Ophthalmology. doi: 10.5301/ejo.5000155. 